Journal of Family Diversity in Education

Volume 1 Number 32015

http://familydiversityeducation.org/index.php/fdec

\title{
Introduction to the Reviews of Vivian Paley's Books
}

Vivian Paley is an early childhood educator who began teaching in the 1950s. She wrote books in which she inquired into the experiences of children and herself in different classrooms over time. Some of her books were set in classrooms other than her own or in childcare settings. At the heart of her inquiries is attention to her developing understanding of the worlds of the children alongside various adults. Paley does not name herself as a curriculum scholar, but her books make visible what we have come to call curriculum making (Clandinin \& Connelly, 1992) in the lives of children. While mostly situated in schools, in some of her books, Paley writes about children's lives in their familial places. The following five book reviews attend to the familial in The Boy Who Would Be a Helicopter: The Uses of Storytelling in the Classroom (1990), In Mrs. Tully's Room: A Childcare Portrait (2001), The Girl with the Brown Crayon (1997), The Boy on the Beach: Building Community Through Play (2010), and You Can't Say You Can't Play (1992).

The authors of these reviews highlighted the familial by metaphorically laying the books alongside their experiences with families, their own and others. What emerges are five reviews that attend to developing further understandings of familial curriculum making (Huber, Murphy, \& Clandinin, 2011) and the possibilities of what might be (Greene, 1995) in understanding children's multiple curriculum making worlds.

\section{References}

Clandinin, D. J., \& Connelly, F. M. (1992). Teacher as curriculum maker. In P. W. Jackson (Ed.), Handbook of research on curriculum, (pp. 363-401). New York, NY: Macmillan.

Greene, M. (1995). Releasing the imagination: Essays on education, the arts, and social change. San Francisco, CA: Jossey-Bass Publishers.

Huber, J., Murphy, M. S., \& Clandinin, D. J. (2011). Places of curriculum making: Narrative inquiries into children's lives in motion. Bingley, UK: Emerald Publishing.

Paley, V. G. (1990). The boy who would be a helicopter. Cambridge, MA: Harvard University Press.

Paley, V. G. (1992). You can't say you can't play. Cambridge, MA: Harvard University Press.

Paley, V. G. (1997). The girl with the brown crayon. Cambridge, MA: Harvard University Press.

Paley, V. G. (2001). In Mrs. Tully's room: A childcare portrait. Cambridge, MA: Harvard University Press.

Paley, V. G. (2010). The boy on the beach: Building community through play. Chicago, IL: The University of Chicago Press.

ISSN 2325-6389 